\title{
Immunotherapy with Sipuleucel-T (APC8015) in patients with metastatic castration-refractory prostate cancer (mCRPC): a systematic review and meta-analysis
}

Tobias Engel Ayer Botrel, Otávio Clark, Antônio Carlos Lima Pompeo, Francisco Flávio Horta Bretas, Marcus Vinicius Sadi, Ubirajara Ferreira, Rodolfo Borges dos Reis

Comitê Brasileiro de Estudos em Uro-Oncologia - CoBEU (ACLP, FFHB, MVS, UF, RBR) and Evidencias(TEAB, OC), São Paulo, Brazil

\section{ABSTRACT}

Objective: To perform a systematic review and meta-analysis of all randomized controlled trials comparing the efficacy of Sipuleucel-T versus placebo for asymptomatic or minimally symptomatic metastatic castration-refractory prostate cancer (mCRPC). Materials ans Methods: Several databases were searched, including MEDLINE, EMBASE, LILACS, and CENTRAL. The endpoints were overall survival (OS), time to progression (TTP) and side effects. We performed a meta-analysis (MA) of the published data. The results are expressed as Hazard Ratio (HR) or Risk Ratio (RR), with their corresponding 95\% confidence intervals (CI 95\%).

Results: The final analysis included 3 trials comprising 737 patients. The TTP was similar in patients who received Sipuleucel-T or placebo (fixed effect: HR $=0.89$; CI 95\% = 0.75 to $1.05 ; \mathrm{p}=0.16$ ), with no heterogeneity detected on this analysis (Chi2 $=2.14$, df $=2(\mathrm{P}=0.34) ; \mathrm{I} 2=6 \%)$. The results showed a higher overall survival in patients treated with Sipuleucel-T (fixed effect: $H R=0.74 ;$ CI 95\% $=0.61$ to $0.89 ; p=0.001 ; \mathrm{NNT}=3$ ). We found no heterogeneity on this analysis either (Chi2 $=1.46, \mathrm{df}=2(\mathrm{P}=0.48)$; I2 = $0 \%$ ). The incidence of adverse events (grade $>3$ ) was the same in both groups.

Conclusion: Sipuleucel-T prolongs overall survival in patients with asymptomatic or minimally symptomatic mCRPC.

\section{ARTICLE INFO}

\section{Key words:}

Immunotherapy;

Sipuleucel-T; Review Literature

as Topic; Meta-analysis

Int Braz J Urol. 2012; 38: 717-27

Submitted for publication:

March 22, 2012

Accepted after revision:

July 19, 2012

\section{INTRODUCTION}

Prostate cancer is the most common non-cutaneous malignancy and the second leading cause of cancer mortality amongst men in the Western world (1). Up to $40 \%$ of men diagnosed with prostate cancer will eventually develop metastatic disease (1). Although androgen deprivation is the standard of care for advanced prostate cancer, patients with metastatic disease eventually progress to a castration-resistant state $(2,3)$.
The average survival for patients with metastatic castration-refractory prostate cancer ( $\mathrm{mCRPC}$ ) is 2 to 3 years (1). Other denominations have also been used in the definition of CRPC, including: hormone-resistant prostate cancer, hormone-refractory prostate cancer, hormone-independent prostate cancer and androgen-independent prostate cancer. CPRC is the most widely accepted term, because even those patients considered resistant to castration, may still show some response to secondary hormonal manipu- 
lations as documented in studies with new drugs such as Abiraterone (4) or MDV3100 (5).

Until recently, we have had few effective therapeutic options for the management of CRPC. Mitoxantrone was the first chemotherapeutic agent that demonstrated clinical activity in CRPC; it was approved in 1996 based on a reportedly improved quality of life (6). New treatment strategies have since been developed. Docetaxel was shown to modestly improve overall survival (OS) in two phase III trials $(7,8)$. Based on these results, docetaxel chemotherapy was approved in 2004 by the US Food and Drug Administration (FDA) as the first-line standard treatment of mCRPC (9).

In 2010, the autologous cellular immunotherapeutic product Sipuleucel-T also received FDA approval for use in patients with asymptomatic or minimally symptomatic mCRPC. This approval indicates immunotherapy as a feasible treatment for CRPC patients $(10,11)$. Currently, most studies are investigating the real efficacy of immunotherapy in patients with metastatic CRPC (11).

Sipuleucel-T, also referred to as APC8015, is an autologous active cellular immunotherapy product designed to stimulate an immune response against prostate cancer. Sipuleucel-T consists of autologous peripheral blood mononuclear cells, including antigen-presenting cells, that have been activated in vitro with a recombinant fusion protein. The recombinant fusion protein PA2024 is composed of prostatic acid phosphatase, an antigen expressed in the majority of prostate adenocarcinomas (12-14).

The first randomized study, published in 2006, showed an increase of 4.5 months in median overall survival, in favor of Sipuleucel-T in patients with mCRPC (15).

However, 3 years later, the final results of the study D9902A were presented and no differences were observed in overall survival between the groups evaluated (14).

In 2010, a larger phase III study, the IMPACT trial, was subsequently published and showed an increase of 4.1 months in median overall survival in favor of the Sipuleucel-T group (16).

To confirm these survival findings, our objective was to analyze all published randomized controlled trials (RCTs) that compared the efficacy of Sipuleucel-T against placebo for asymptomatic or minimally symptomatic mCRPC.

\section{MATERIALD AND METHODS}

\section{Study Selection Criteria \\ Types of Studies \\ We included RCTs with parallel design that compared the use of Sipuleucel-T (autologous ac- tive cellular immunotherapy) and placebo.}

Types of participants

The selected studies included patients with radiologic evidence of metastases, asymptomatic or minimally symptomatic castration-refractory prostate cancer (progressive disease with serum testosterone level of less than $50 \mathrm{ng} / \mathrm{dL}$ or $17 \mathrm{nmoL} /$ liter) and without visceral metastases.

Search strategy for identification of studies

A wide search on the main computerized databases was conducted, including EMBASE, LILACS, MEDLINE, SCI, CENTRAL, The National Cancer Institute Clinical Trials service, and The Clinical Trials Register of Trials Central. In addition, the abstracts published in the proceedings of the American Society of Clinical Oncology (ASCO), the European Society for Medical Oncology (ESMO), Society of Urologic Oncology (SUO) were also searched.

For MEDLINE, we used the search strategy methodology for randomized controlled trials (17) recommended by the Cochrane Collaboration (18). For EMBASE, we used adaptations of this same strategy (17), and for LILACS, we used the search strategy methodology reported by Castro et al. (19). We performed an additional search on the SCI database looking for studies that were cited on the included studies. We added the specific terms pertinent to this review to the overall search strategy methodology for each database.

The overall search strategy was as follows: \# 1 ("Immunotherapy"(Mesh) AND "Prostatic Neoplasms"(Mesh); \#2 Random*

Searches of electronic databases combined the terms: \# 1 AND \# 2 for these study designs: 
Humans, Clinical Trial, Meta-Analysis, Practice Guideline, Randomized Controlled Trial, and Review.

\section{Critical Evaluation of the Selected Studies}

All the references retrieved by the search strategies had their title and abstract evaluated by two of the researchers. Every reference with the least indication of fulfilling the inclusion criteria was listed as pre-selected. We retrieved the complete article of all pre-selected references. They were analyzed by two different researchers and included or excluded according to the previously reported criteria. The excluded trials and the reason of their exclusion are listed in this article. Data was extracted from all the included trials.

Details regarding the main methodology characteristics empirically linked to bias (20) were extracted with the methodological validity of each selected trial assessed by two reviewers (T.E.A.B and 0.C). Particular attention was given to some items such as: the generation and concealment of the sequence of randomization, blinding, application of intention-to-treat analysis, sample size predefinition, loss of follow-up description, adverse events reports, if the trial was multi-centric and the sponsorship.

\section{Data Extraction}

Two independent reviewers extracted data. The name of the first author and year of publication were used to identify the study. All data were extracted directly from the text or calculated from available information when necessary. The data of all trials were based on the intention-to-treat principle, so they compared all patients allocated in one treatment with all those allocated in the other.

The primary endpoints were overall survival (OS) and time to progression (TTP). TTP was defined as the time from randomization to the time of disease progression. Disease progression included any of the following: 1) progressive disease on serial radiographic imaging tests; 2) new cancer-related pain associated with a radiographic anatomical correlation; or 3) other clinical events consistent with progression such as spinal cord compression, nerve root compression, or pathologic fracture.
Other clinical outcomes evaluated included the number of patients that presented adverse events (AEs) (grade $\geq 3$ ): chills, fatigue, fever (pyrexia), back pain, headache, arthralgia, asthenia, nausea, anemia, vomiting and prostate-specific antigen (PSA) reduction of $\geq 50 \%$.

\section{Analysis and Presentation of Results}

Data were analyzed using the Review Manager 5.0.24 statistical package (Cochrane Collaboration Software) (21).

Dichotomous clinical outcomes are reported as Risk Ratio (RR) and survival data as Hazard Ratio (HR) (22). The corresponding 95\% confidence interval (CI 95\%) was calculated, considering $\mathrm{P}$ values less than $5 \%(\mathrm{p}<0.05)$. A statistic for measuring heterogeneity was calculated through I2 method (25\% was considered low-level heterogeneity, 25-50\% moderate-level heterogeneity and > 50\% high-level heterogeneity) $(23,24)$.

To estimate the absolute gains in TTP and OS, we calculated the meta-analytic survival curves as suggested by Parmar et al. (22). A pooled estimate of the HR was computed by a fixed-effect model according to the inverse-variance method (25). Thus, for effectiveness an HR or RR greater than one favors the standard arm (Placebo) whereas an HR or RR less than 1 favors the Sipuleucel-T treatment.

If statistical heterogeneity was found in the meta-analysis, we performed an additional analysis using the random-effects model described by DerSimonian and Laird (26), that provides a more conservative analysis.

To assess the possibility of publication bias, we performed the funnel plot test described by Egger et al. (27). When the pooled results were significant, the number of patients needed to treat (NNT) to cause or to prevent one event was calculated by pooling absolute risk differences in trials included in meta-analyses (28-30). For all analyses, a forest plot was generated to display results.

\section{RESULTS}

The diagram represents the flow of identification and inclusion of trials, as recommended by the PRISMA statement (Preferred Reporting 
Items for Systematic Reviews and Meta-Analyses) (31) (Figure-1).

Overall, 754 references were identified and screened.

Forty-five studies were selected and retrieved for full-text analysis. Of these studies, 42 were excluded for various reasons, described on Table-1 (additional material).

The final analysis included 3 trials comprising 737 patients. All trials were randomized (Sipuleucel-T or control), double-blinded, placebo-controlled and multi-centric. The primary endpoint was TTP in two studies $(14,15)$ and OS in one study (16) (Table-2). was performed with acetaminophen and an antihistamine such as diphenhydramine (14-16).

Reductions in PSA levels $\geq 50 \%$ were equally detected in both groups (fixed effect: $R R=$ 0.98 ; CI $95 \%=0.96$ to $1.00 ; p=0.07$ ). We found no heterogeneity on this analysis $\left(\mathrm{Chi}^{2}=0.68\right.$, df $\left.=1(\mathrm{P}=0.41) ; \mathrm{I}^{2}=0 \%\right)$ (Figure-2).

The TTP was similar in patients who received Sipuleucel-T or placebo (fixed effect: HR $=0.89 ; \mathrm{CI} 95 \%=0.75$ to $1.05 ; \mathrm{p}=0.16)$ without indications of heterogeneity on this analysis $\left(\mathrm{Chi}^{2}\right.$ $\left.=2.14, \mathrm{df}=2(\mathrm{P}=0.34) ; \mathrm{I}^{2}=6 \%\right)$ (Figure-3).

The results showed a higher overall survival in patients treated with Sipuleucel-T (fi-

Figure 1 - Trial selection flow.

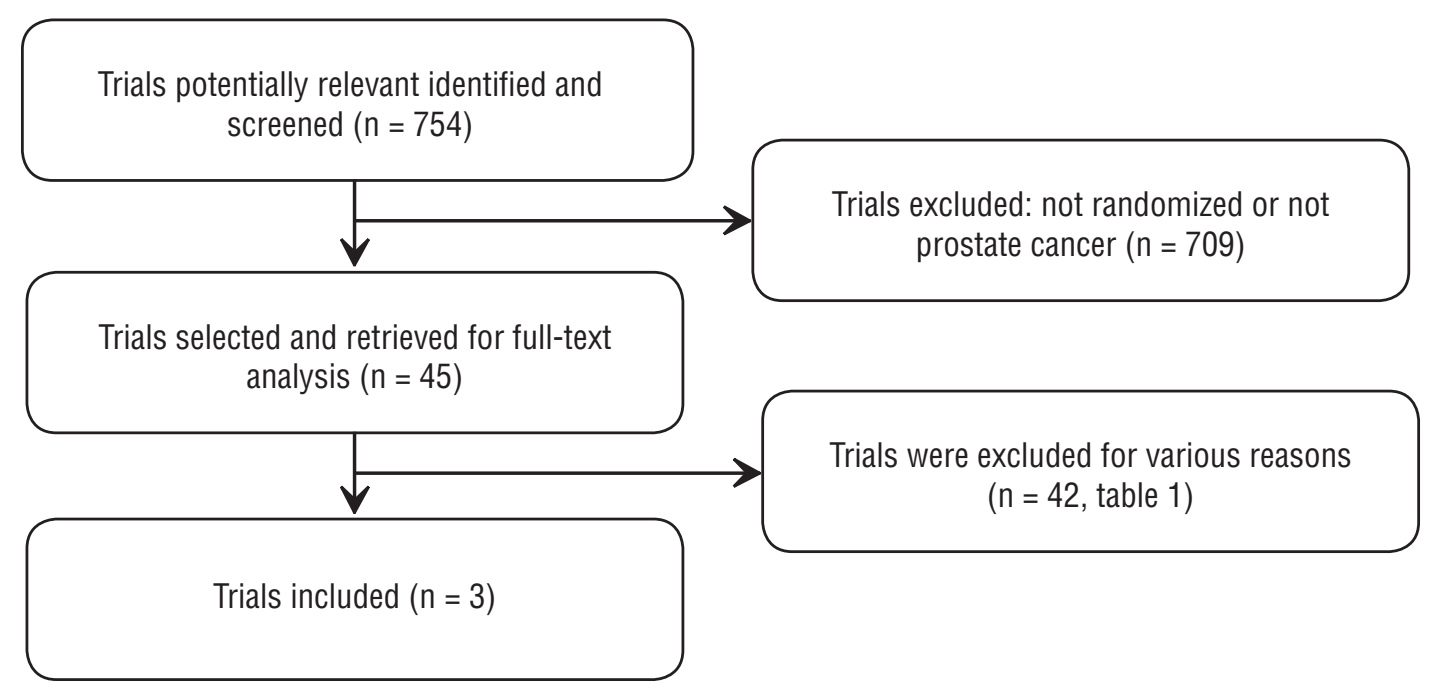

Patients were randomly assigned in a $2: 1$ ratio to receive either Sipuleucel-T or placebo every 2 weeks, for a total of three infusions. In all studies, concurrent bisphosphonates therapy and previous chemotherapy were allowed, but patients with visceral metastases were excluded (14-16).

Patients without prior bilateral orchiectomy continued on gonadal suppression with a luteinizing hormone-releasing hormone agonist throughout the trials. In all studies, pretreatment xed effect: $H R=0.74 ;$ CI $95 \%=0.61$ to $0.89 ; p$ $=0.001 ; \mathrm{NNT}=3$ ), again without heterogeneity $\left(\mathrm{Chi}^{2}=1.46, \mathrm{df}=2(\mathrm{P}=0.48) ; \mathrm{I}^{2}=0 \%\right)$ (Figure-4). The incidence of grade $\geq 3$ adverse events was the same in both groups: chills $(\mathrm{RR}=6.13$; $\mathrm{CI}$ $95 \%=0.81$ to 46.73$)$, fatigue $(\mathrm{RR}=0.94$; CI $95 \%$ $=0.26$ to 3.39), fever (pyrexia) $(\mathrm{RR}=0.66 ; \mathrm{CI} 95 \%$ $=0.16$ to 2.61), back pain $(\mathrm{RR}=0.89 ; \mathrm{CI} 95 \%=$ 0.40 to 1.98$)$, headache $(R R=2.04 ;$ CI $95 \%=0.23$ to 18.12), arthralgia $(\mathrm{RR}=0.96 ; \mathrm{CI} 95 \%=0.35$ 


\section{Table 1 - Characteristics of Excluded Studies.}

\begin{tabular}{|c|c|}
\hline Study & Reason for Exclusion \\
\hline Beer 2011 (39) & Androgen-dependent prostate cancer \\
\hline Sanda $1999(40)$ & Not a randomized trial \\
\hline Madan 2009 (41) & Not a randomized trial \\
\hline Antonarakis 2010 (42) & Not a randomized trial \\
\hline Cha 2011 (43) & Not a randomized trial \\
\hline Joniau 2011 (44) & Not a randomized trial \\
\hline Madan 2010 (45) & Not a randomized trial \\
\hline May 2011 (46) & Not a randomized trial \\
\hline Morse 2010 (47) & Not a randomized trial \\
\hline McLeod 2011 (48) & A subgroup analysis \\
\hline Fizazi 2011 (49) & Androgen-dependent prostate cancer \\
\hline Beer 2011 (50) & Androgen-dependent prostate cancer \\
\hline Penson 2006 (51) & Integrated analysis of studies analyzed (Small and Higano) \\
\hline Sonpavde 2011 (52) & Not a randomized trial \\
\hline Beltran 2011 (1) & Not a randomized trial \\
\hline Drake 2010 (53) & Not a randomized trial \\
\hline Cha 2010 (2) & Not a randomized trial \\
\hline Harzstark 2009 (54) & Not a randomized trial \\
\hline Mohebtash 2008 (55) & Not a randomized trial \\
\hline Vaishampayan 2008 (56) & Not a randomized trial \\
\hline Harzstark 2008 (57) & Not a randomized trial \\
\hline Barqawi 2007 (58) & Not immunotherapy \\
\hline Arlen 2007 (59) & Not a randomized trial \\
\hline Di Lorenzo 2007 (60) & Not a randomized trial \\
\hline
\end{tabular}


Table 2 - Characteristics of Included Studies.

\begin{tabular}{lccccc}
\hline Study & N & Patients & Desing & Interventions & Primary endpoint \\
\hline $\begin{array}{l}\text { Small 2006 } \\
(15)\end{array}$ & 127 & $\begin{array}{c}\text { Asymptomatic } \\
\text { metastatic CRPC }\end{array}$ & $\begin{array}{c}\text { Randomized, double-blind, } \\
\text { placebo-controlled, } \\
\text { multicenter }\end{array}$ & $\begin{array}{c}\text { Sipuleucel-T } \\
\text { Placebo }\end{array}$ & $\begin{array}{c}\text { Time to disease } \\
\text { progression }\end{array}$ \\
$\begin{array}{l}\text { Higano 2009 } \\
(14)\end{array}$ & 98 & $\begin{array}{c}\text { Asymptomatic } \\
\text { metastatic CRPC }\end{array}$ & $\begin{array}{c}\text { Randomized, double-blind, } \\
\text { placebo-controlled, } \\
\text { multicenter }\end{array}$ & $\begin{array}{c}\text { Sipuleucel-T } \\
\text { Placebo }\end{array}$ & $\begin{array}{c}\text { Time to disease } \\
\text { progression }\end{array}$ \\
$\begin{array}{l}\text { Kantoff 2010 } \\
(16)\end{array}$ & 512 & $\begin{array}{c}\text { Asymptomatic or } \\
\text { minimally sympto- } \\
\text { matic CRPC }\end{array}$ & $\begin{array}{c}\text { Randomized, double-blind, } \\
\text { placebo-controlled, } \\
\text { multicenter }\end{array}$ & $\begin{array}{c}\text { Sipuleucel-T } \\
\text { Placebo }\end{array}$ & Overall survival \\
\hline
\end{tabular}

Figure 2 - Comparative effect in reduction of PSA $>\mathbf{5 0} \%$ of Sipuleucel-T versus Placebo.

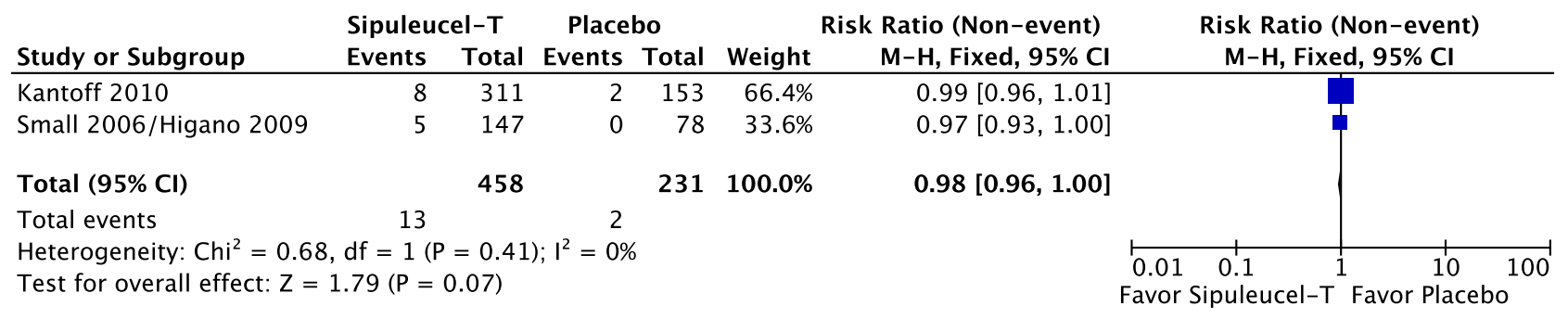

Figure 3 - Comparative effect in time to progression of Sipuleucel-T versus Placebo.

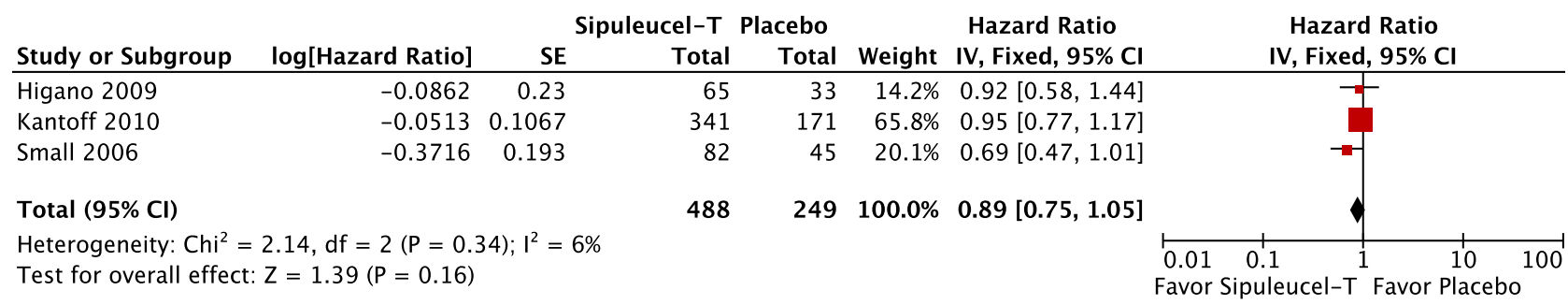

Figure 4 - Comparative effect in overall survival of Sipuleucel-T versus Placebo.

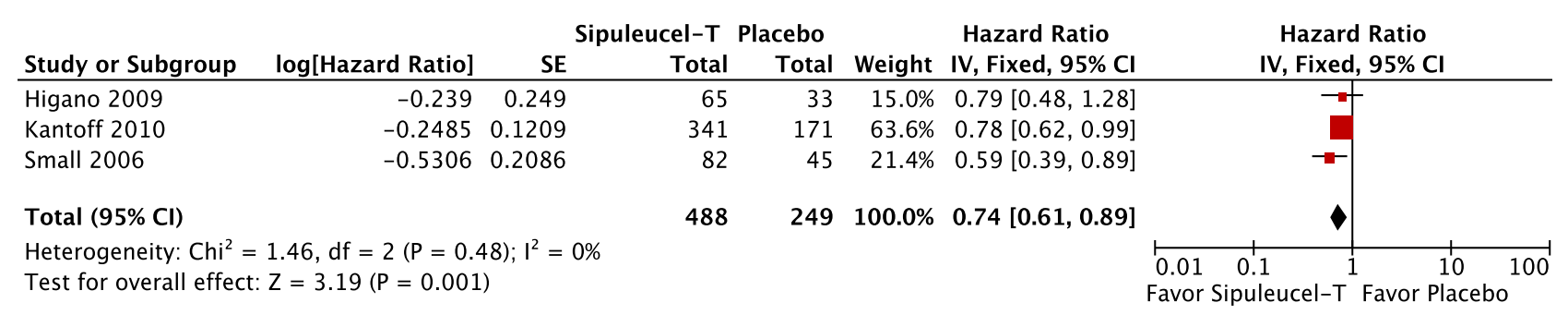


to 2.66), asthenia ( $R R=1.49$; $C I 95 \%=0.30$ to 7.31), nausea ( $R R=2.03$; CI $95 \%=0.23$ to 18.10$)$, anemia $(\mathrm{RR}=0.78$; CI $95 \%=0.31$ to 1.92$)$ and vomiting $(\mathrm{RR}=1.56$; $\mathrm{CI} 95 \%=0.06$ to 37.86$)(\mathrm{Fi}-$ gure-5).

According to the funnel plot analysis (27) the possibility of publication bias was low for all of the endpoints.

\section{DISCUSSION}

Vaccine-based therapies seek to directly stimulate a specific immune reaction against a single or multi-tumor antigens (11).

The four main types of vaccines that have been investigated for CRPC can be classified as

Figure 5 - Adverse events (grade $>3$ ) of patients treated with Sipuleucel-T versus Placebo.

\begin{tabular}{|c|c|c|c|c|c|c|c|}
\hline Study or Subgroup & \multicolumn{2}{|c|}{ Sipuleucel-T } & \multicolumn{2}{|c|}{ Control } & \multicolumn{2}{|r|}{ Risk Ratio } & $\begin{array}{c}\text { Risk Ratio } \\
\text { M-H, Fixed, 95\% Cl }\end{array}$ \\
\hline \multicolumn{8}{|l|}{ 3.1.1 Chills } \\
\hline Kantoff 2010 & 4 & 338 & 0 & 168 & $50.4 \%$ & $4.49[0.24,82.85]$ & \\
\hline $\begin{array}{l}\text { Small 2006/Higano } 2009 \\
\text { Subtotal }(95 \% \mathrm{CI})\end{array}$ & 7 & $\begin{array}{l}147 \\
485\end{array}$ & 0 & $\begin{array}{r}76 \\
244\end{array}$ & $\begin{array}{r}49.6 \% \\
100.0 \%\end{array}$ & $\begin{array}{r}7.80[0.45,134.84] \\
6.13[0.81,46.73]\end{array}$ & \\
\hline \multirow{2}{*}{\multicolumn{8}{|c|}{$\begin{array}{l}\text { Heterogeneity: } C h i^{2}=0.07, d f=1(P=0.79) ; I^{2}=0 \% \\
\text { Test for overall effect: } Z=1.75(P=0.08)\end{array}$}} \\
\hline & & & & & & & \\
\hline Kantoff 2010 & 4 & 338 & 3 & 168 & $85.9 \%$ & $0.66[0.15,2.93]$ & \\
\hline $\begin{array}{l}\text { Small 2006/Higano } 2009 \\
\text { Subtotal }(95 \% \mathrm{CI})\end{array}$ & 2 & $\begin{array}{l}147 \\
485\end{array}$ & 0 & $\begin{array}{r}76 \\
244\end{array}$ & $\begin{array}{r}14.1 \% \\
\mathbf{1 0 0 . 0 \%}\end{array}$ & $\begin{array}{r}2.60[0.13,53.51] \\
0.94[0.26,3.39]\end{array}$ & \\
\hline \multirow{2}{*}{\multicolumn{8}{|c|}{$\begin{array}{l}\text { Heterogeneity: } C \mathrm{ii}^{2}=0.65, \mathrm{df}=1(P=0.42) ; \mathrm{I}^{2}=0 \% \\
\text { Test for overall effect: } Z=0.10(P=0.92)\end{array}$}} \\
\hline & & & & & & & \\
\hline Kantoff 2010 & 1 & 338 & 3 & 168 & $85.9 \%$ & $0.17[0.02,1.58]$ & \\
\hline $\begin{array}{l}\text { Small 2006/Higano } 2009 \\
\text { Subtotal }(95 \% \mathrm{CI})\end{array}$ & 3 & $\begin{array}{l}147 \\
485\end{array}$ & 0 & $\begin{array}{r}76 \\
244\end{array}$ & $\begin{array}{r}14.1 \% \\
\mathbf{1 0 0 . 0 \%}\end{array}$ & $\begin{array}{r}3.64[0.19,69.61] \\
0.66[0.16,2.61]\end{array}$ & \\
\hline \multirow{2}{*}{\multicolumn{8}{|c|}{$\begin{array}{l}\text { Heterogeneity: } \mathrm{Chi}^{2}=2.73, \mathrm{df}=1(\mathrm{P}=0.10) ; \mathrm{I}^{2}=63 \% \\
\text { Test for overall effect: } Z=0.60(P=0.55)\end{array}$}} \\
\hline & & & & & & & \\
\hline Kantoff 2010 & 12 & 338 & 8 & 168 & $89.0 \%$ & $0.75[0.31,1.79]$ & \\
\hline $\begin{array}{l}\text { Small 2006/Higano } 2009 \\
\text { Subtotal }(95 \% \mathrm{CI})\end{array}$ & 4 & $\begin{array}{l}147 \\
485\end{array}$ & 1 & $\begin{array}{r}76 \\
244\end{array}$ & $\begin{array}{r}11.0 \% \\
\mathbf{1 0 0 . 0 \%}\end{array}$ & $\begin{array}{r}2.07[0.24,18.18] \\
0.89[0.40,1.98]\end{array}$ & \\
\hline $\begin{array}{l}\text { Total events } \\
\text { Heterogeneity: } \mathrm{Chi}^{2}=0.7 \\
\text { Test for overall effect: } \mathrm{Z}=\end{array}$ & $\begin{array}{l}16 \\
d f=1(P \\
28(P=\end{array}$ & $\begin{array}{l}=0.39) \\
(78)\end{array}$ & $\stackrel{9}{9} I^{2}=0 \%$ & & & & \\
\hline 3.1.5 Headache & & & & & & & \\
\hline Kantoff 2010 & 1 & 338 & 0 & 168 & $50.4 \%$ & $1.50[0.06,36.52]$ & \\
\hline $\begin{array}{l}\text { Small 2006/Higano } 2009 \\
\text { Subtotal }(95 \% \mathrm{CI})\end{array}$ & 2 & $\begin{array}{l}147 \\
485\end{array}$ & 0 & $\begin{array}{r}76 \\
244\end{array}$ & $\begin{array}{r}49.6 \% \\
100.0 \%\end{array}$ & $\begin{array}{l}2.60[0.13,53.51] \\
2.04[0.23,18.12]\end{array}$ & \\
\hline $\begin{array}{l}\text { Total events } \\
\text { Heterogeneity: } \mathrm{Chi}^{2}=0.0 \\
\text { Test for overall effect: } \mathrm{Z}=\end{array}$ & $\begin{array}{l}3 \\
d f=1(P \\
.64(P=\end{array}$ & $\begin{array}{l}=0.80) \\
.52)\end{array}$ & ; $I^{2}=0 \%$ & & & & \\
\hline 3.1.6 Arthralgia & & & & & & & \\
\hline Kantoff 2010 & 7 & 338 & 5 & 168 & $91.0 \%$ & $0.70[0.22,2.16]$ & \\
\hline $\begin{array}{l}\text { Small 2006/Higano } 2009 \\
\text { Subtotal }(95 \% \mathrm{CI})\end{array}$ & 3 & $\begin{array}{l}147 \\
485\end{array}$ & 0 & $\begin{array}{r}76 \\
244\end{array}$ & $\begin{array}{r}9.0 \% \\
100.0 \%\end{array}$ & $\begin{array}{r}3.64[0.19,69.61] \\
0.96[0.35,2.66]\end{array}$ & \\
\hline $\begin{array}{l}\text { Total events } \\
\text { Heterogeneity: } \mathrm{Chi}^{2}=1.0 \\
\text { Test for overall effect: } \mathrm{Z}=\end{array}$ & $\begin{array}{c}10 \\
\mathrm{df}=1(\mathrm{P} \\
.08(\mathrm{P}=\end{array}$ & $\begin{array}{l}=0.30) \\
.94)\end{array}$ & $; l^{2}=\stackrel{5}{9 \%}$ & & & & \\
\hline
\end{tabular}




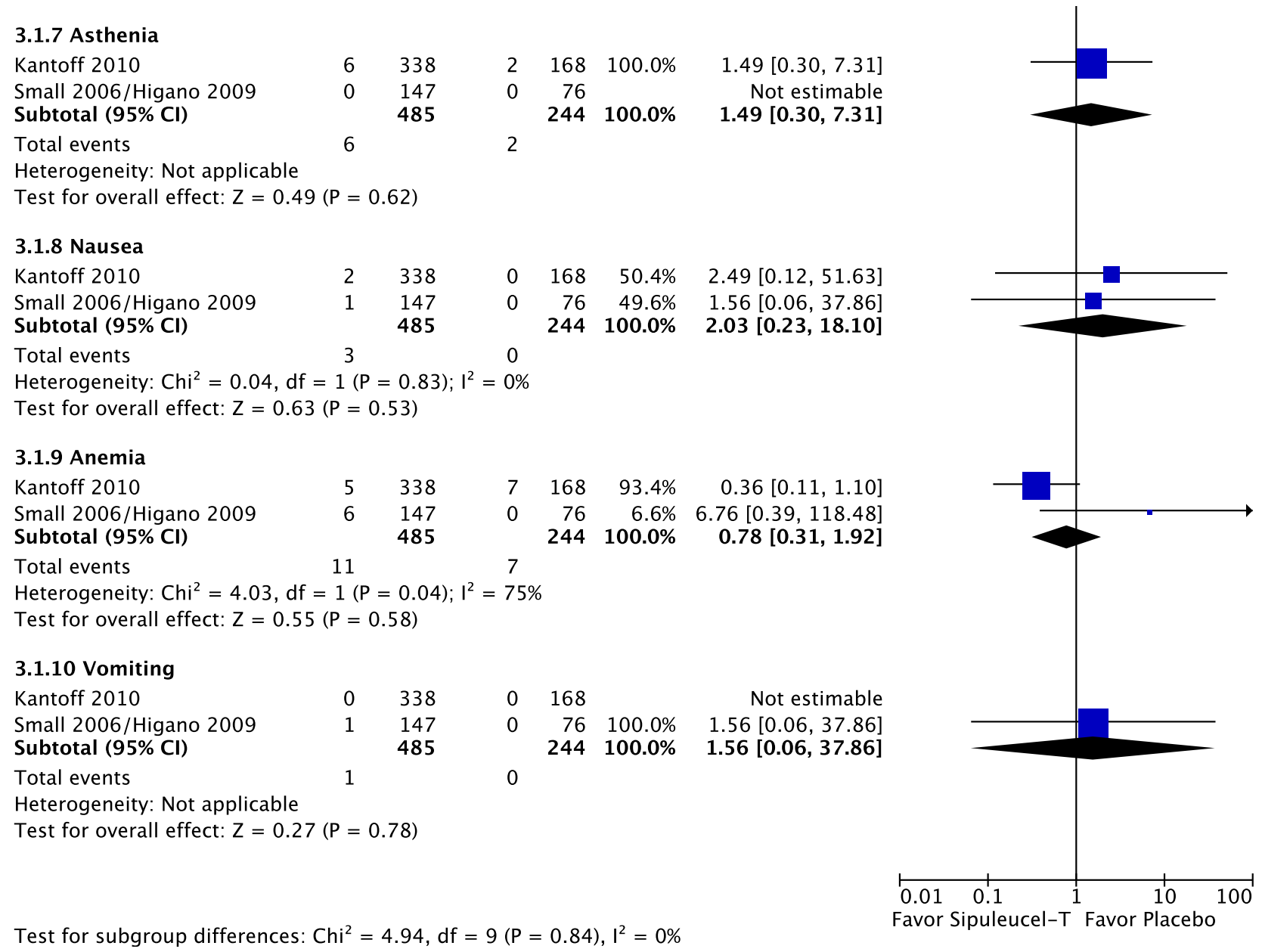

viral vector based, cell based, DNA vaccines, and autologous (derived from a patient's own tumor cells) (11).

Sipuleucel-T in this meta-analysis reduced the risk of death by $26 \%$. In contrast to overall survival, the time to progression for the respective diseases and reduction in PSA levels did not differ significantly between Sipuleucel-T and placebo. This may be due to the delayed onset of antitumor responses after active immunotherapy, relative to objective disease progression (16). Other randomized clinical trials have also demonstrated that benefits in overall survival were not linked to effects in time to progression (32) or vice versa $(16,33)$.

Similarly, PSA level declines have not consistently been a surrogate endpoint for survival, particularly in CRPC trials. The TAX327 trial is one example (34). In that trial, the docetaxel given every 3 weeks arm and the weekly docetaxel arm had essentially similar PSA > 50\% decline rates (45\% and 48\%, respectively) yet only the every 3 week regimen demonstrated a survival advantage compared to mitoxantrone (35).

In the study by Kantoff (16) most patients had a PSA response rate measured at least twice during treatment. In the integrated analysis of two other studies included in this analysis (14) only $26 \%$ of patients had $\geq$ two PSA values measured at least 4 weeks apart. Therefore the PSA response rate may be underestimated (14).

The most common AEs associated with Sipuleucel-T treatment were chills, fatigue, fever (pyrexia), back pain, and headache. These AEs are generally consistent with cytokine release, as observed after the administration of other immunotherapies (36). Most AEs developed within one day 
of infusion were grade $1 / 2$ in severity and resolved in 2 days or less (37).

Docetaxel and Cabazitaxel, other FDA approved therapies that confer a survival advantage in $\mathrm{mCRPC}$ cases, are associated with grade $3 / 4$ hematological toxicities and infections in 5\% to $82 \%$ of patients $(7,37,38)$. Abiraterone acetate, a potent inhibitor of CYP17 and androgen synthesis, also demonstrated improved survival in men with metastatic CRPC with progression after docetaxel chemotherapy. The most common adverse events included fluid retention, hypokalemia and hypertension (4). None of these have been compared in head to head trials or against Sipuleucel-T so we still do not know which is the better option.

Despite the encouraging results, there are many unresolved questions regarding immunotherapy, including the best clinical setting for immunotherapy (the rational combination and proper sequencing of Sipuleucel-T with other newly approved agents) and the definition of relevant clinical and immunological endpoints (2).

\section{CONCLUSIONS}

Sipuleucel-T prolongs the survival of patients with asymptomatic or minimally symptomatic mCRPC. The time to progression was the same of both groups. No grade 3/4 AEs were reported in 5\% or more of patients.

\section{CONFLICT OF INTEREST}

None declared.

\section{REFERENCES}

1. Beltran H, Beer TM, Carducci MA, de Bono J, Gleave M, Hussain $M$, et al.: New therapies for castration-resistant prostate cancer: efficacy and safety. Eur Urol. 2011; 60: 279-90.

2. Cha E, Fong L: Therapeutic vaccines for prostate cancer. Curr Opin Mol Ther. 2010; 12: 77-85.

3. Chang SS, Kibel AS: The role of systemic cytotoxic therapy for prostate cancer. BJU Int. 2009; 103: 8-17.

4. de Bono JS, Logothetis CJ, Molina A, Fizazi K, North S, Chu $\mathrm{L}$, et al:: Abiraterone and increased survival in metastatic prostate cancer. N Engl J Med. 2011; 364: 1995-2005.
5. Scher HI, Beer TM, Higano CS, Anand A, Taplin ME, Efstathiou E, et al.: Antitumour activity of MDV3100 in castration-resistant prostate cancer: a phase 1-2 study. Lancet. 2010; 375: 1437-46.

6. Tannock IF, Osoba D, Stockler MR, Ernst DS, Neville AJ, Moore MJ, et al.: Chemotherapy with mitoxantrone plus prednisone or prednisone alone for symptomatic hormoneresistant prostate cancer: a Canadian randomized trial with palliative end points. J Clin Oncol. 1996; 14: 1756-64.

7. Tannock IF, de Wit R, Berry WR, Horti J, Pluzanska A, Chi $\mathrm{KN}$, et al.: Docetaxel plus prednisone or mitoxantrone plus prednisone for advanced prostate cancer. N Engl J Med. 2004; 351: 1502-12.

8. Petrylak DP, Tangen CM, Hussain MH, Lara PN Jr, Jones JA, Taplin ME, et al.: Docetaxel and estramustine compared with mitoxantrone and prednisone for advanced refractory prostate cancer. N Engl J Med. 2004; 351: 1513-20.

9. Bianchini D, Zivi A, Sandhu S, de Bono JS: Horizon scanning for novel therapeutics for the treatment of prostate cancer. Ann Oncol. 2010; 21(Suppl 7): 43-55.

10. Peskin SR: Immunotherapy for advanced prostate cancer: a novel treatment option to improve survival. Manag Care. 2011; 20: 6-11.

11. Gerritsen WR, Sharma P: Current and emerging treatment options for castration-resistant prostate cancer: a focus on immunotherapy. J Clin Immunol. 2012; 32: 25-35.

12. Goldstein NS: Immunophenotypic characterization of 225 prostate adenocarcinomas with intermediate or high Gleason scores. Am J Clin Pathol. 2002; 117: 471-7.

13. Haines AM, Larkin SE, Richardson AP, Stirling RW, Heyderman E: A novel hybridoma antibody (PASE/4LJ) to human prostatic acid phosphatase suitable for immunohistochemistry. Br J Cancer. 1989; 60: 887-92.

14. Higano CS, Schellhammer PF, Small EJ, Burch PA, Nemunaitis $\mathrm{J}$, Yuh $\mathrm{L}$, et al.: Integrated data from 2 randomized, double-blind, placebo-controlled, phase 3 trials of active cellular immunotherapy with sipuleucel-T in advanced prostate cancer. Cancer. 2009; 115: 3670-9.

15. Small EJ, Schellhammer PF, Higano CS, Redfern $\mathrm{CH}, \mathrm{Ne}-$ munaitis JJ, Valone FH, et al.: Placebo-controlled phase III trial of immunologic therapy with sipuleucel-T (APC8015) in patients with metastatic, asymptomatic hormone refractory prostate cancer. J Clin Oncol. 2006; 24: 3089-94.

16. Kantoff PW, Higano CS, Shore ND, Berger ER, Small EJ, Penson DF, et al.: Sipuleucel-T immunotherapy for castration-resistant prostate cancer. N Engl J Med. 2010; 363: 411-22.

17. Dickersin K, Scherer R, Lefebvre C: Identifying relevant studies for systematic reviews. BMJ. 1994; 309: 1286-91.

18. Clarke M, Oxman AD, (Eds). Cochrane Reviewers Handbook 4.1.1 [updated December 2000] In: The Cochrane Library, Issue 4, 2000. Oxford, Update Software, 2000. 
19. Castro AA, Clark OA, Atallah NA: Optimal search strategy for clinical trials in the Latin American and Caribbean Health Science Literature database (LILACS database): update. Sao Paulo Med J. 1999; 117: 138-9.

20. Egger M, Smith GD, Altman D: Systematic Reviews in Health Care. London: BMJ Books. 2001.

21. Review Manager (RevMan) [Computer program]. Current version: 5.0.24 Copenhagen: The Nordic Cochrane Centre. The Cochrane Collaboration, 2008 (updated on 16 April 2010).

22. Parmar MK, Torri V, Stewart L: Extracting summary statistics to perform meta-analyses of the published literature for survival endpoints. Stat Med. 1998 30; 17: 2815-34. Erratum in: Stat Med. 2004; 23: 1817.

23. Higgins JP, Thompson SG, Deeks JJ, Altman DG: Measuring inconsistency in meta-analyses. BMJ. 2003; 327: 557-60.

24. Yang K, Wang YJ, Chen XR, Chen HN: Effectiveness and safety of bevacizumab for unresectable non-small-cell lung cancer: a meta-analysis. Clin Drug Investig. 2010; 30: $229-41$.

25. Deeks JJ HJ, Altman DG: Analysing and presenting results, in Higgins JP, Green S (eds): Cochrane Handbook for Systematic Reviews of In- terventions (ed 4.2.6 [updated September 2006]). Chichester, United Kingdom, John Wiley \& Sons, Ltd. 2006.

26. DerSimonian $\mathrm{R}$, Laird N: Meta-analysis in clinical trials. Control Clin Trials. 1986; 7: 177-88.

27. Egger M, Davey Smith G, Schneider M, Minder C: Bias in meta-analysis detected by a simple, graphical test. BMJ. 1997; 315: 629-34.

28. McQuay HJ, Moore RA: Using numerical results from systematic reviews in clinical practice. Ann Intern Med. 1997; 126: 712-20.

29. Smeeth L, Haines A, Ebrahim S: Numbers needed to treat derived from meta-analyses--sometimes informative, usually misleading. BMJ. 1999; 318: 1548-51.

30. Altman DG, Deeks JJ: Meta-analysis, Simpson's paradox, and the number needed to treat. BMC Med Res Methodol. 2002; 2 : 3.

31. Liberati A, Altman DG, Tetzlaff J, Mulrow C, Gøtzsche PC, Ioannidis JP, et al.: The PRISMA statement for reporting systematic reviews and meta-analyses of studies that evaluate health care interventions: explanation and elaboration. Ann Intern Med. 2009; 151: W65-94.

32. James ND, Caty A, Borre M, Zonnenberg BA, Beuzeboc $P$, Morris $T$, et al.: Safety and efficacy of the specific endothelin-A receptor antagonist ZD4054 in patients with hormone-resistant prostate cancer and bone metastases who were pain free or mildly symptomatic: a double-blind placebo-controlled, randomised, phase 2 trial. Eur Urol. 2009; 55: 1112-23.
33. Sternberg CN, Petrylak DP, Sartor 0, Witjes JA, Demkow T, Ferrero JM, et al.: Multinational, double-blind, phase III study of prednisone and either satraplatin or placebo in patients with castrate-refractory prostate cancer progressing after prior chemotherapy: the SPARC trial. J Clin Oncol. 2009; 27: 5431-8.

34. Tannock IF, de Wit R, Berry WR, Horti J, Pluzanska A, Chi KN, et al.: Docetaxel plus prednisone or mitoxantrone plus prednisone for advanced prostate cancer. N Engl J Med. 2004; 351: 1502-12.

35. Berthold DR, Pond GR, Soban F, de Wit R, Eisenberger M, Tannock IF: Docetaxel plus prednisone or mitoxantrone plus prednisone for advanced prostate cancer: updated survival in the TAX 327 study. J Clin Oncol. 2008; 26: 242-5.

36. Dillman R0: Infusion reactions associated with the therapeutic use of monoclonal antibodies in the treatment of malignancy. Cancer Metastasis Rev. 1999; 18: 465-71.

37. Hall SJ, Klotz L, Pantuck AJ, George DJ, Whitmore JB, Frohlich MW, et al.: Integrated safety data from 4 randomized, double-blind, controlled trials of autologous cellular immunotherapy with sipuleucel-T in patients with prostate cancer. J Urol. 2011; 186: 877-81.

38. de Bono JS, Oudard S, Ozguroglu M, Hansen S, Machiels JP, Kocak I, et al.: Prednisone plus cabazitaxel or mitoxantrone for metastatic castration-resistant prostate cancer progressing after docetaxel treatment: a randomised openlabel trial. Lancet. 2010; 376: 1147-54.

39. Beer TM, Bernstein GT, Corman JM, Glode LM, Hall SJ, Poll WL, et al.: Randomized trial of autologous cellular immunotherapy with sipuleucel-T in androgen-dependent prostate cancer. Clin Cancer Res. 2011; 17: 4558-67.

40. Sanda MG, Smith DC, Charles LG, Hwang C, Pienta KJ, Schlom J, et al.: Recombinant vaccinia-PSA (PROSTVAC) can induce a prostate-specific immune response in androgen-modulated human prostate cancer. Urology. 1999; 53: 260-6.

41. Madan RA, Arlen PM, Mohebtash M, Hodge JW, Gulley JL. Prostvac-VF: a vector-based vaccine targeting PSA in prostate cancer. Expert Opin Investig Drugs. 2009; 18: 1001-11.

42. Antonarakis ES, Drake CG: Current status of immunological therapies for prostate cancer. Curr Opin Urol. 2010; 20: 241-6.

43. Cha E, Fong L: Immunotherapy for prostate cancer: biology and therapeutic approaches. J Clin Oncol. 2011; 29: 3677-85.

44. Joniau S, Abrahamsson PA, Bellmunt J, Figdor C, Hamdy F, Verhagen $P$, et al.: Current vaccination strategies for prostate cancer. Eur Urol. 2012; 61: 290-306.

45. Madan RA, Gulley JL: The current and emerging role of immunotherapy in prostate cancer. Clin Genitourin Cancer. 2010; 8: 10-6. 
46. May KF, Jr., Gulley JL, Drake CG, Dranoff G, Kantoff PW: Prostate cancer immunotherapy. Clin Cancer Res. 2011; 17: 5233-8.

47. Morse MA, Whelan M: A year of successful cancer vaccines points to a path forward. Curr Opin Mol Ther. 2010; 12: 11-3.

48. McLeod DG, Quinn DI, Whitmore JB, Tabesh M, editors. Sipuleucel-T in African Americans: A subgroup analysis of three phase III sipuleucel-T trials in advanced prostate cancer. J Clin Oncol. 2011; 29: (Suppl; abstr e15148).

49. Fizazi K, Powles T, George DJ, Poehlein CH, editors. A randomized, controlled phase III global trial comparing sipuleucel-T plus androgen deprivation therapy versus androgen deprivation therapy alone in men with metastatic androgen dependent (hormone sensitive) prostate cancer. J Clin Oncol. 2011; 29: (Suppl; abstr TPS188).

50. Beer TM, Schellhammer PF, Corman JM, Glode LM, Hall $\mathrm{S}, \mathrm{Xu} \mathrm{Y}$, et al.:, editors. Quality-of-life assessment in a randomized, double-blind study of sipuleucel-T in men with androgen-dependent prostate cancer. J Clin Oncol. 2011; 29: (Suppl; abstr 4648).

51. Penson J, Holzbeierlein PA, Schellhammer MW, editors. Study results of active cellular immunotherapy with Sipuleucel-T in androgen independent prostate cancer suggest significant survival benefit with minimal toxicity. http://suonetorg/pdf/ProgramBooks/2006_SU0_ProgramBookpdf Poster \#44.
52. Sonpavde G, Agarwal N, Choueiri TK, Kantoff PW: Recent advances in immunotherapy for the treatment of prostate cancer. Expert Opin Biol Ther. 2011; 11: 997-1009.

53. Drake CG, Antonarakis ES: Update: immunological strategies for prostate cancer. Curr Urol Rep. 2010; 11: 202-7.

54. Harzstark AL, Small EJ: Immunotherapeutics in development for prostate cancer. Oncologist. 2009; 14: 391-8.

55. Mohebtash M, Madan RA, Gulley JL, Arlen PM: Therapeutic prostate cancer vaccines: a review of the latest developments. Curr Opin Investig Drugs. 2008; 9: 1296-301.

56. Vaishampayan $\mathrm{U}$, Hussain M: Update in systemic therapy of prostate cancer: improvement in quality and duration of life. Expert Rev Anticancer Ther. 2008; 8: 269-81.

57. Harzstark AL, Ryan CJ: Therapies in development for castrate-resistant prostate cancer. Expert Rev Anticancer Ther. 2008; 8: 259-68.

58. Barqawi $A B$, Crawford ED: The current use and future trends of focal surgical therapy in the management of localized prostate cancer. Cancer J. 2007; 13: 313-7.

59. Arlen PM, Skarupa L, Pazdur M, Seetharam M, Tsang KY, Grosenbach DW, et al.: Clinical safety of a viral vector based prostate cancer vaccine strategy. J Urol. 2007; 178(4 Pt 1):1515-20.

60. Di Lorenzo G, Autorino R, Figg WD, De Placido S: Hormone-refractory prostate cancer: where are we going? Drugs. 2007; 67: 1109-24.

\footnotetext{
Correspondence address:

Dr. Tobias Engel Ayer Botrel

Rua Santos Dumond 241 / 71

Poços de Caldas, MG, 37701-171, Brazil

Telephone: + 5535 9140-0067

E-mail: tobias.engel@evidencias.com.br
} 